\title{
Influence of Airborne and Seed Inoculum in the Initiation of Leaf, Stem, and Root Infection by Systemic Botrytis cinerea in Lettuce (Lactuca sativa) Yahaya SM*, Fagwalawa LD and Lawan M
}

Department of Biology, Kano University of Science and Technology Wudil P, M.B.3244, Kano State-Nigeria

\begin{abstract}
Studies showed that both airborne seed infection of B.cinerea have been implied as major sources of primary inoculum in different part of lettuce plant. Results from quantitative real-time PCR and visual observations showed that seed infection was the main source of inoculum in the field trial conducted in this study. However, glasshouse studies established that the pathogen can be transmitted from infected seeds into roots, shoots and leaves without showing symptoms. Plants in the field trial remained free of infection for approximately four months before symptoms were observed in the crop. Covering the crop during part of the growing season was found to prevent the growth of the pathogen, despite the use of infected seed, which indicate that changes in the physiological condition of the plant and/or environmental conditions most especially over watering may trigger disease development. However, once the disease symptoms appeared in the field it quickly spread throughout the plants. Level of inoculum equivalent to spore concentrations between 30 and 60 spores per $\mathrm{m}^{3}$ of air was only detected on three occasions during the growing season. The temporal pattern and level of detection of $B$. cinerea DNA in spore tape samples indicated that airborne inoculum was limited and most likely represented rain-splashed conidia rather than putative ascospores.
\end{abstract}

Keywords: B.cinerea; Lettuce plant; Real-time PCR; Seed infection; Spore trap

\section{Introduction}

Lettuce Lactuca sativa (Asteraceae; Compositae) is one of the World's most important salad crops and horticulturists regard it as one of the most profitable to grow [1]. Leaf, stem, root and seed infections caused by systemic $B$. cinerea are common in lettuce grown in the whole of the UK [2], Infection of lettuce plants by B. cinerea is favoured by cool moist weather conditions [3,4]. However, the levels of disease in crops can alter from year to year, with the cost of losses in winter lettuce estimated at $£ 257$ million due to $B$. cinerea infection alone in fungicide-treated crops [5]. Initial infection can result from infected lettuce stubble and/or crop debris on the soil [6,7] and most commonly occurs when successive lettuce crops have been grown in the same field. Symptom development in the fields with no previous record of lettuce cropping can arise from the sowing of infected seed or by infection from air-dispersed spores. Once infection is established in a crop, the infected lettuce plants show abundant white, cottony mycelial growth and hard, black sclerotic bodies on the underside of the lower leaves and the basal part of the stem [4]. The head and stem of infected plants often disintegrates into a soft watery mass covered with sclerotia [8].

It has been reported by $[1,2,9]$ that $B$. cinerea infection was seedborne, and it is thought that seed infection could be extremely important for the spread of $B$. cinerea into new areas with no record of lettuce cultivation $[10,11]$. In another study Shafia [12] found that the efficacy of disease transmission on seeds was dependent on the rate of seed germination and temperature, $[1,10,13]$ showed that root, stem, leaf infection could develop from symptomless seeds. The symptoms of $B$. cinerea infection generally occur and can be identified by the presence of dense gray or light brown airborne spores (ascospores or conidia), which may require high humidity and free water for infection to occur $[8,14,15]$. Recent work using DNA-based markers has confirmed that $B$. cinerea populations are highly genetically variable, with the majority of variation distributed within individual fields $[16,17]$. These findings agree with the results of $\mathrm{Ma}$ and Michailides, Martin [18] who reported moderate genetic variation within $B$. cinerea isolates collected from fig plants in the same location in California however, differences between different hosts. Similarly, this was similarly Newton [19] reported that population of $B$. cinerea from different host's species (Strawberry, dandelion, black current, primula) sampled from different locations of the UK were genetically variable and most importantly highly variable within host plants. The objective of this study therefore, was to determine the role of seeds and airborne inoculum in the initiation of B. cinerea infection in leaf, stem, root and seed infection of lettuce plant in a field experiment where crop debris was excluded as a potential inoculum source. Covering the crop until disease symptoms appeared in the remaining plots was to test the hypothesis that conidia and ascospore release from plant material in autumn and winter could initiate leaf and stem infection in lettuce plant.

\section{Materials and Methods}

\section{Field trial}

The area designated for the research has been cropped with lettuce for the last five years, having been fallow for the last two years. The Nearest lettuce stubble field was at least $0.8 \mathrm{~km}$ away and the plots were about $500 \mathrm{~m}$ from grassland. The whole field measured $33 \times 14$ $\mathrm{m}$ and contained 12 small plots $(3 \times 3 \mathrm{~m})$. The lettuce plots were either sown with 'clean' seed from Fothergills Seeds, New market, UK or from 'infected' seed harvested in the previous experiment from untreated plots at School of Biological Science, Reading. The certified lettuce seeds supplied by Fothergills Seeds, New market had been assessed

*Corresponding author: Yahaya SM, Department of Biology, Kano University of Science and Technology Wudil P, M.B.3244 Kano State-Nigeria, E-mail: sanimyahya@gmail.com

Received November 13, 2015; Accepted December 14, 2015; Published December 18, 2015

Citation: Yahaya SM, Fagwalawa LD, Lawan M (2015) Influence of Airborne and Seed Inoculum in the Initiation of Leaf, Stem, and Root Infection by Systemic Botrytis cinerea in Lettuce (Lactuca sativa). J Plant Pathol Microbiol 6: 323. doi:10.4172/2157-7471.1000323

Copyright: @ 2015 Yahaya SM, et al. This is an open-access article distributed under the terms of the Creative Commons Attribution License, which permits unrestricted use, distribution, and reproduction in any medium, provided the original author and source are credited. 
Citation: Yahaya SM, Fagwalawa LD, Lawan M (2015) Influence of Airborne and Seed Inoculum in the Initiation of Leaf, Stem, and Root Infection by Systemic Botrytis cinerea in Lettuce (Lactuca sativa). J Plant Pathol Microbiol 6: 323. doi:10.4172/2157-7471.1000323

experimentally and were found to be free of disease symptoms, whereas most of the infected seeds showed symptoms of $B$. cinerea both on the surface and interior of the seeds. All seeds were sown without the use of seed treatments on 2 January 2010.

Specially designed tents made from aluminium tubing and acetate clear plastics were placed in the centre of selected plots to exclude airborne inoculum [1]. By covering the crop, the effect of excluding conidia and airborne spores as an inoculum source, which is an issue in other closely related species such as light leaf spot of oilseed rape (Pyrenopeziza brassicae), could be tested in the period of the growing season when ascospores release is anticipated. The covers were later removed to determine whether the clean lettuce plants which had been excluded from airborne inoculum could subsequently become infected. The use of Arabidopsis plants between the plots was to help minimise the spread of inoculum from plot to plot via rain splash. The mini tents were secured in the soil to a depth of $250 \mathrm{~mm}$, covering all the plants in the centre square metre of each plot in a 'miniature greenhouse'. All the tents were thoroughly and regularly checked and any hole noticed was repaired using parcel tape until the development of disease symptoms, there after all the tents were removed from the trial plots. None of the plots in the field experiment received any fungicide treatments throughout the growing season, however, all other inputs were made according to standard farm practice with a spring application of 167 $\mathrm{kg}$ ha one of ammoniacal nitrogen $18.4 \%$, nitric $\mathrm{N} 11.6 \%$ and watersoluble sulphur (SO3) 19.0\% (Sulphur Gold, TERRA Nitrogen UK Ltd).

\section{Field trial sampling and visual assessments}

Assessments in the field were carried out every week. The study used conventional visual plant pathological techniques, in combination with spore trapping and quantitative real-time PCR which was developed previously [20] to check for the development of disease symptoms, until the time that they first appeared in multiple plots, symptoms were visible in all uncovered plots sown with infected seeds. All tents were then removed and plants were sampled from each of the nine, $1 \mathrm{~m}^{2}$ subplots, contained in all 12 of the main plots. The visual assessments for $B$. cinerea in leaves and stems were carried out by counting the number of lesions on whole plants, and the plant growth stages were also recorded for each subset of 10 plants sampled. After assessment of the disease, all the plants were discarded except for the 10 plant samples from the central $1 \mathrm{~m}^{2}$ subplot. Plants from this subplot were then further dissected, were each of the plant was separated into roots, white stems (colourless and located below the surface of the soil), green stems (found above the surface of the soil) and leaves (10 of each for each plant section, from three replicates). These were then frozen for future DNA extraction and PCR testing. The same procedure was used for the samples taken on 24 April 2010. Also visual assessments was performed on 10 plants per plot each month throughout the growing season.

\section{Trapping of airborne inoculum}

A seven-day recording volumetric spore trap Burkard (Burkard Manufacturing Co. Ltd.) was set up in the central strip of the field immediately after the crop was sown Arabidopsis. A $3^{\mathrm{m}}$ radius directly surrounding the spore trap was kept clear to decrease rain splashdispersed spores being sucked into the trap. The spores were collected on Melinex polyester film tape (Burkard Manufacturing) coated with a mixture of paraffin wax and petroleum jelly. The tape was replaced every seven days. For analysis, the tape was cut into $48 \mathrm{~mm}$ sections, each representing a $24 \mathrm{~h}$ period.

\section{DNA extraction and quantification of $B$. cinerea DNA using real-time PCR}

DNA was extracted from all sampled plant and fungal material using the method of $[1,21]$ except that the DNA extraction buffer was

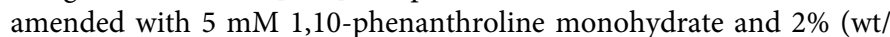
vol) polyvinylpyrrolidone $\mathrm{K} 30$ (Sigma-Aldrich Chemie $\mathrm{GmbH}$ ) to clean the DNA [22]. The DNA was quantified using the fluorescent dye thiazole orange (Sigma-Aldrich) as described previously [21]. Spore tape DNA extractions were done using Ballotini beads (Jencons Ltd.) in a Fast Prep machine (Savant Instruments) as described by Calderon et al. [23]. DNA was extracted from half of each 24-h tape sample and $1 \mathrm{lL}$ from $200 \mathrm{lL}$ final DNA solution was used in each PCR assay. Quantitative real-time PCR measurements were carried out in a Strata gene Mx3000P real-time PCR machine (Stratagene, La Jolla, California, USA) with the cytochrome b Locked Nucleic Acid (LNA) probe assay recently developed [20].

\section{Determination of $B$. cinerea seed infection and its transmission in controlled environment}

Seeds from the two seed batches used in the field experiment were visually assessed and tested by real-time PCR to establish differences in seed infection levels and to determine whether symptomless seeds were infected with $B$. cinerea. Five seeds with and without symptoms were randomly selected on the grain surface of each seed batch and analysed. For the controlled environment study, five hundred seeds from each seed batch were sampled. Each seed was thoroughly examined with a hand lens and were separated into seed lots with and without symptoms. Symptomless seeds from the 'clean' seed batch and seeds with symptoms from the infected' seed batch were sown into autoclaved compost (John Innes, No 2) in propagator trays $(50 \times 20 \mathrm{~cm})$ and incubated at separate controlled environment cabinets (Fisons $600 \mathrm{H}$ ). The light intensity used was 2001 Einsteinm)2 s)1 PAR. After germination, the seedlings in the trays were watered daily, so that the soil remained damp regardless of the incubation temperature. Seedlings were sampled at growth stage 8-9 (coleoptiles breaking through soil surface) and at 14-15 (4 or 5 leaves unfolded). The samples were collected on different sampling dates, as the growth of the seedlings differ.

The basic aluminium frame of the tent manufactured from $2.5 \mathrm{~cm}$ diameter tubing. Ten seedlings were sampled at each growth stage using ethanol-cleaned forceps. Seedlings were dissected into lower root, seed, upper root and above soil stem/leaf sections and B. cinerea infection levels determined using real-time PCR. Microscopy was carried out according to the methods developed $[1,19]$ to examine the plant material for fungal structures of $B$. cinerea.

\section{Data analysis}

The visual observations and quantitative real-time PCR data sets were transformed using natural logarithms, $\ln (x+0.5)$ for visual data and $\ln (\mathrm{x}+0.1)$ for PCR data, to normalize the residuals from fitted models. Results was examined with a 2-way analysis of variance (ANOVA) using Genstat, 14th edition, (VSN International, Ltd), with plant, plot and block as random factors. The weather data for the 20092010 growing season were obtained from the Meteorological Database.

\section{Results}

\section{Effect of seed source and covering of plants on leaf infection}

The first symptom of leaf blotch, a single lesion in one of the plots drilled with infected seed, was seen on 3 February 2010. The tents were removed two weeks later when all uncovered plots sown with farm- 
Citation: Yahaya SM, Fagwalawa LD, Lawan M (2015) Influence of Airborne and Seed Inoculum in the Initiation of Leaf, Stem, and Root Infection by Systemic Botrytis cinerea in Lettuce (Lactuca sativa). J Plant Pathol Microbiol 6: 323. doi:10.4172/2157-7471.1000323

saved infected seed showed symptoms. Plants from farm-saved seed had an average of 5.6 lesions per plant compared to the symptomless clean seed, which had only 0.18 lesions per plant (Table 1 ). However, covering the crop significantly reduced the formation of symptoms; at the time the tents were removed, there was no symptoms in any of the covered areas, whether drilled with symptomless infected or uninfected seed. Disease was recorded in seedlings surrounding the tents in the same plots (data not shown). However, after removal of the tents, disease levels in these previously covered areas remained lower than in plots that had not been covered. While in the covered plots, disease levels in plots drilled with uninfected clean seed remained much lower than in those drilled with farm-saved infected seed, and the same effect was also seen for the plots that were not covered. Results obtained from the ANOVA on all plots found that tenting greatly reduced symptoms of B. cinerea $(\mathrm{P}<0.001)$ and plots sown with uninfected clean seed had less disease than plots sown with infected seed $(\mathrm{P}<0.001)$. Statistically, the interaction was significant $(\mathrm{P}<0.001)$ because the covered plants were free of symptoms regardless of seed source. The difference between the seed types and the effect of covering the crop with tents both remained highly significant $(\mathrm{P}<0.001)$ for up to two months after the removal of the tents. However, four months after removal of the tents disease severity levels were relatively closer. The main effect differences were highly significant $(\mathrm{P}=0.006$ for seed source, $\mathrm{P}<0.001$ for tenting) and the interaction was not significant $(\mathrm{P}=0.4)$.

\section{Detection of $B$. cinerea in plant samples using real-time PCR}

All plant materials roots, stem and leaves sampled from plots which were not covered, had detectable amounts of $B$. cinerea. DNA in realtime PCR throughout the trial. However, plant samples from uncovered plots sown with an infected seeds had higher levels of $B$. cinerea than those collected from uncovered plots sown with uninfected clean seeds. The roots sampled from uncovered plots sown with an infected seeds contained around $6 \mathrm{pg} \mathrm{B}$. cinerea DNA, compared to around $0.6 \mathrm{pg}$ for the uninfected seeds. The PCR results from the February samples showed that no $B$. cinerea DNA could be detected in samples from plots sown with either the infected seed (plots 4, 7 and 11) or symptomless uninfected seeds when grown undercover. Nearly all plant parts sampled from all plots contained B. cinerea DNA April 2010. The highest levels of $B$. cinerea DNA were mostly found in the leaves and decreased towards the roots. $B$. cinerea DNA levels were lower in plots sown with uninfected seed $(\mathrm{P}<0.001)$ and in covered plots $(\mathrm{P}<0.001)$. The interaction between seed and cover was significant, showing that covering prevented disease development even when the seed was heavily infected with $B$. cinerea $(\mathrm{P}<0.001)$. The differences in $B$. cinerea DNA levels between the different plant parts (roots, seeds, stems and leaves) were also significant $(\mathrm{P}<0.001)$ as was the interaction between plant parts and cover $(\mathrm{P}<0.001)$. Patterns and levels of significance were similar on both sampling dates (Table 1).

\section{Detection of airborne inoculum of $B$. cinerea}

Botrytis cinerea DNA was not detected in spore tape samples collected between October and December. However, small daily amounts of $B$. cinerea DNA, $<2 \mathrm{pg}$, were detected between January and July during the period of the growing season when leaf symptoms was visible. Detection of airborne inoculum was not linked with rainfall events (data not shown). Assuming a detection threshold of $0.1 \mathrm{pg}$ of pathogen DNA in a $24 \mathrm{~h}$ air sample is equivalent to approximately 3 spores $\mathrm{m}) 3$ [21] B. cinerea spore concentrations between 30 and 60 spores $\mathrm{m}) 3$ was only detected on three occasions. Anything detected below the threshold of $0.1 \mathrm{pg}$ of pathogen is regarded as zero and not within the scope of this research.

\section{Seed infection and transmission of disease in controlled environment}

Seeds with symptoms had approximately twice as much $B$. cinerea DNA as randomly-selected seeds from the same batch (Table 2). Most seeds without symptoms tested positive for presence of $B$. cinerea in real-time PCR. However, the average infection level of seeds sampled from the symptomless clean seed batch was approximately 10 -fold lower than seeds sampled from the farm-saved infected seed batch, irrespective of the sampling method.

Most parts of plants produced from symptomless uninfected seed tested negative for $B$. cinerea DNA at all stages of growth and temperatures tested (data not shown). As expected, more samples were positive for $B$. cinerea infection when infected seeds were sown 6). The highest levels of pathogen DNA was detected after growth at 16_C. At this temperature, DNA of B. cinerea was detected in all plant parts sampled at growth stage 8-9 and 14-15. None of the plants grown in the controlled environment showed any symptoms of leaf infection at growth stage 14-15. No spores or hyphal / mycelium structures resembling $B$. cinerea was seen in any of the samples examined by light microscopy.

\section{Discussion}

The emergence of the lettuce seedling under the covers was quicker

\begin{tabular}{|c|c|c|c|}
\hline Seed & Tent cover & Leaf gray mold & ${\text { Leaf gray } \text { mold }^{\mathbf{2}}}^{\mathbf{2}}$ \\
\hline \multirow{2}{*}{ Uninfected seed } & open & 0.19 & 53 \\
\cline { 2 - 4 } & Tented & 0 & 0.95 \\
\hline \multirow{2}{*}{ Infected seed } & open & 5.61 & 11.3 \\
\cline { 2 - 4 } & & 0 & 3.5 \\
\hline cv of mean & & $13 \%$ & $22 \%$ \\
\hline
\end{tabular}

Disease was expressed as number of lesions per plant. It was analysed on log scale: main effects and interaction significant $(P<0.001$, df 1,6$)$. Block and plot variances not significantly larger than plant variance. $B$. cinerea.

${ }^{2}$ Disease expressed as number of lesions per plant. It was analysed on log scale: main effects of seed source, $P<0.006$ (1,6 df); tenting $P<0.001$. Interaction $P=0.4$ Blocks did not differ more than expected from plot-plot variation, but this was significantly more than plant-plant variation $(\mathrm{P}<0.001 ; 6108 \mathrm{df})$.

The coefficient of variation from sem on log scale; the variability applies to any mean in the column closer, the main effect differences were highly significant $(P=0.006$ for seed source, $P<0.001$ for tenting) and the interaction was no longer significant $(\mathrm{P}=0.4)$

Table 1: Visual assessment of plant $B$. cinerea. Samples were taken from the centre $1 \mathrm{~m}^{2}$ subplot of plots of lettuce grown from clean (symptomless) or infected seed sources and covered or left open until then. Ten plants per subplot were assessed. Back transformed mean values per plant are given.

\begin{tabular}{|c|c|c|c|}
\hline Seed lot & $\begin{array}{l}\text { sampling } \\
\text { method }^{1}\end{array}$ & visual symptom ${ }^{2}$ & $\begin{array}{l}\text { pathogen DNA } \\
(\mathrm{Pg}) \text { per sample }\end{array}$ \\
\hline \multirow{2}{*}{ Uninfected seed } & At Random & 0 & 0.18 \\
\hline & Selective & 1.2 & 0.26 \\
\hline \multirow{2}{*}{ Infected seed } & At Random & 0.6 & 1.53 \\
\hline & Selective & 1.2 & 3.0 \\
\hline $\begin{array}{l}\text { SED or Proportionate error } \\
\text { In each mean }\end{array}$ & & 0.26 & $34 \%$ \\
\hline
\end{tabular}

${ }^{1}$ Seeds that were randomly selected or selected for symptoms of $B$. cinerea infection.

2Symptom visual scores; 0 , no symptoms; 1 , flecking symptoms; 2 , lesions visible. Main effect of sampling method, $P<0.001$; seed lot and interaction $P>0.1$, not significant.

${ }^{3}$ Back-transformed mean; analysis on log scale (equivalent to the measurement scale). ANOVA: main effect of seed lot, $\mathrm{P}<0.001$; sampling method and interaction $P>0.2$, not significant.

Table 2: Level of $B$. cinerea in clean (symptomless) or infected $B$. cinerea seed of various origins, determined by visual assessments and quantitative real-time PCR. 
by about one week because of the warmer climate and thus the plants grow at a faster rate throughout the growing season. On the day that the tents were removed (growth stage 23-24), there were clear effects of both covering and seed batches on the epidemic development of $B$. cinerea (Table 1). Plants in symptomless open plots sown with uninfected seeds had significantly less disease than open plots sown with infected seed. These results were supported by the real-time PCR data. All plant parts (roots, stems and leaves) sampled from plots sown with infected seeds showed higher levels of $B$. cinerea DNA than equivalent samples taken from plots sown with uninfected seeds. Detection of $B$. cinerea in all of the plant parts sampled indicates a systemic infection spreading from the seed. However, the greater infection levels were always found in infected uncovered seed and these caused greater disease levels throughout the growing season when compared to all the other seed types and conditions. Botrytis cinerea was initially not detected in plants sampled from covered subplots, irrespective of seed source for reasons which are unclear. Suppression of disease development in the covered crop may have been due to the differences in soil water potential which could have influenced rhizosphere bacterial communities involved in disease suppression. Another possible explanation may be the environmental conditions for the covered crop may not have been conducive for the fungal growth as it may have been too warm and dry, but ideal for greater plant growth enabling disease escape. Also Shafia [12] demonstrated that the rate of germination of a seedling could prevent the infection occurring at increased temperature higher than the optimal 16_C) by causing the coleoptiles to grow away more rapidly from the infected area of the seed. Winter lettuce is now drilled as early as possible in the UK, when the soil temperature will be higher and therefore this should reduce the effective transmission of $B$. cinerea from seed to seedlings.

However, during this experiment no data for the environmental impact of the covers were taken so it is not possible to determine what factors caused the lack of both visual disease and positive PCR results for samples taken from under covers in February from both infected and uninfected seed. Four weeks after the removal of the tents, $B$. cinerea DNA was detected in plant samples from all plots and this was eventually followed by leaf gray mold symptoms (Table 1). This may be due to a delayed spread of inoculum from the seed following a change in the environment, because highest levels of pathogen DNA were still recorded for plant parts (including roots) sampled from plots sown with the infected seed. However, it is also possible that infection may have developed from the outside plots following the removal of the covers and these plants could have been more susceptible to symptom development due to their earlier 'softer' growth environment containing elevated temperatures and humidity and reduced amounts of other outside factors such as wind and frost. The development of a similar disease pattern following the removal of the covers is probably the results of conidia spreading across all the plots with the exception of the infected uncovered seed plots which has initially higher pathogen levels because of the role of seed infection detection threshold were detected in spore tape samples from the end of January until the end of July 2010 with the occasional higher level of up to $1.9 \mathrm{pg}$ of pathogen DNA. This pattern is not typical of other ascospore-producing fungi present in other arable crops such as Mycosphaerella graminicola, Pyrenopeziza brassicae and Oculimacula yallundae, which all tend to produce ascospores more abundantly from senesced plants and / or stubble during late summer to early winter. Moreover, these pathogens also produce some spores during late spring to summer $[1,23,24]$. The period in which positive tape samples were detected coincided largely with the period that symptoms were visible on the leaves and not during late summer to early winter. Because of the low level of detection in comparison with other ascospore producing pathogens, it is likely that the $B$. cinerea DNA detected originated from asexual spores, rather than from ascospores. Therefore, it was suggested that sexual recombination events may be common in populations of $B$. cinerea, and this may therefore, be the major reason for its epidemiology and adaptation to the environment $[17,25,26]$. Asexual spores of $B$. cinerea are relatively small in comparison with asexual spores of other fungi and therefore during humid conditions, water droplets containing spores could have been sucked directly into the spore trap. It was not possible to identify ascospores of $B$. cinerea by examining the spore tapes by microscopy since the morphology of the teleomorph is unknown. In order to identify ascospores in positive samples, work now needs to be carried out to develop an immunofluorescence microscopy assay using specific antibodies or in situ PCR to positively identify the source of fungal material that is causing a positive result for spore tape DNA samples.

In the controlled environment study however, no root, stem or leaf symptoms were seen throughout the experiment. But, $B$. cinerea DNA was detected in seedlings from both infected and uninfected seeds at all temperatures used. Out of the temperatures tested, 16_C was optimal for B. cinerea, confirming earlier work [12]. However, [11] using competitive PCR demonstrated that visual assessments poorly corroborate with levels of $B$. cinerea DNA from the same seed.

Plant roots were colonized by $B$. cinerea in both the controlled environment and the field experiments. There was as previous report of $B$. cinerea infection on the root system, and affected plants had reduced root length [27]. In 2003 [28] isolated B. cinerea from the roots of Primula plant, and recent work [29] has suggested that soil borne inoculum and root infection could be important in the development of rice blast disease, caused by Magnaporthe grisea. This fungus had previously been regarded as a foliar pathogen however, [29] were able to show that root colonization can lead to systemic invasion and development of disease on aerial parts of the plant. Unfortunately, no infection structure of $B$. cinerea was seen by light microscopy. Understanding which stages/structures of $B$. cinerea are important for the infection process and its life cycle could be investigated by green fluorescent protein technology to visualize by confocal microscopy, fungal development in plant [30]. The role of seed infection as primary inoculum for leaf and stem gray mold disease of $B$. cinerea in winter lettuce crops in the UK has probably been over looked because of the long latency of the disease. It is clear that $B$. cinerea can be transmitted from seeds, but may produce no symptoms in the plant for several months (latent infection), and currently almost all of the commercial seed treatments used by growers are not active against $B$. cinerea infection contained in the seed. But changes in the physiological condition of the plant andor environmental conditions may trigger disease development. Seed borne infection may also contribute to the genetic variation of $B$. cinerea populations as batches of seed are often combined and travel for long distances before being sown. In addition to using resistant lettuce varieties and foliar fungicide applications, the testing of seed batches for $B$. cinerea by PCR, with rejection of severely contaminated batches, or additional seed treatments with fungicides might improve disease control. In addition to this more work is needed to establish what levels of seed infection can be tolerated before rejection should occur as most of the clean symptomless seeds used in this study were later found to be infected. Seed batches can also be tested for the presence of alleles conferring resistance to fungicides. Mutations in cytochrome $b$ and $b$-tubulin encoding genes, targets for the quinone outside inhibitors (QoI) and methyl benzimidazole carbamate (MBC) fungicides, respectively, have been identified in populations of $B$. cinerea [31]. Seed infection may also be a reason behind the 
Citation: Yahaya SM, Fagwalawa LD, Lawan M (2015) Influence of Airborne and Seed Inoculum in the Initiation of Leaf, Stem, and Root Infection by Systemic Botrytis cinerea in Lettuce (Lactuca sativa). J Plant Pathol Microbiol 6: 323. doi:10.4172/2157-7471.1000323

introduction of populations of $B$. cinerea, resistant to compounds such as QoI fungicides. The quinone outside inhibitors fungicide resistance that was developed in France during the summer of 2008 [32] may pose a greater risk to the UK growers if seed is imported from an infected area. Therefore, on the final note routine monitoring of seed and other source of $B$. cinerea inoculum using PCR should become vital for the long term viability of lettuce cropping in the UK.

\section{Acknowledgement}

Thanks to Val and Matthew for their assistance in the field and contro environment experiment. Sue and George for their assistance in the molecular work.

\section{References}

1. Skoropad WP (1959) Seed and seedling infection of barley by Rhynchosporium secalis. Phytopathology 49: 623-626.

2. Wheeler IE, Kendall SJ, Butters JA, Hollomon DW, Hall L (1995) Using allelespecific oligonucleotide probes to characterize benzimidazole resistance in Rhynchosporium secalis. Pesticide Science 43: 201-209.

3. Kay JG, Owen H (1973) Transmission of Rhynchosporium secalis on barley grain. Transactions of the British Mycological Society 60: 405-411.

4. Halasi JK, Pajkert AA, Liljana R, Dokic S (2008) Fungal diseases of some vegetables grown in greenhouse and garden. Nature 144: 123-134.

5. Hardwick NV, Slough JE, Gladders P (2002) Winter Barley: A Survey of Disease 2002. York, UK: Central Science Laboratory.

6. Fitt BDL, Creighton NF, Lacey ME, McCartney HA (1986) Effects of rainfal intensity and duration on dispersal of Rhynchosporium secalis conidia from infected barley leaves. Transactions of the British Mycological Society 86: 611-618.

7. Sowley ENK (2006) Epidemiology of Botrytis cinerea, PhD Thesis, University of Reading, UK.

8. Cho J (2008) Winter diseases of lettuce. Commodity fact sheet, Vegetable. University of Hawaii Institute of Tropical Agriculture and Human Resource.

9. Shaw MW, Royle DJ (1989) Airborne inoculum as a major source of Septoria tritici (Mycosphaerella graminicola) infections in winter-wheat crops in the UK. Plant Pathology 38: 35-43.

10. Habgood RM (1971) Transmission of Rhynchosporium secalis by infected barley seed. Plant Pathology 20: 80-81.

11. Lee HK, Tewari JP, Turkington TK (2001) Symptomless infection of barley seed by Rhynchosporium secalis. Canadian Journal of Plant Pathology 23: 315-317.

12. Shafia A (2009) Latent infection of B. cinerea. PhD Thesis University of Reading. UK.

13. Haupt fleisch K (1929) Studies of barley leaf blotch. Nachrichtenblatt Pflanzenschutz DDR 9: 27-28.

14. Brunner PC, Schurch S, McDonald BA (2007) The origin and colonization history of the barley scald pathogen Rhynchosporium secalis. Journal of Evolutionary Biology 20: 1311-1321.

15. Kern DL, Palumbo JC, Sanchez CA, Still DW, Tickes BR, et al. (2006)
Guidelines for head lettuce production in Arizona. Integrated pest management. Cooperative Extension. Series number 12. College of Agriculture and life.

16. Ma Z, Michailides TJ (2005) Genetic structure of $B$. cinerea populations from different hosts in California. Plant Disease 89:1083-1089.

17. Rohel EA, Payne AC, Fraaije BA, Hollomon DW (2001) Exploring infection of wheat and carbohydrate metabolism in Mycosphaerella graminicola transformants with differentially regulated green fluorescent protein expression. Molecular Plant- Microbe Interactions 14: 156-163.

18. Martin PJ (1980) Effect of Rhynchosporium secalis on the growth of barley. Long Ashton Research Station Report for 1979. Long Ashton, UK: Long Ashton Research Station pp. 83-84.

19. Newton AC (1989) Somatic recombination in Rhynchosporium secalis. Plant Pathology 38: 71-74

20. Fountaine JM, Shaw MW, Napier B, Ward E, Fraaije BA (2007) Application of real-time and multiplex PCR assays to study leaf blotch epidemics in barley. Phytopathology 97: 297-303

21. Fraaije BA, Lovell DJ, Rohel EA, Hollomon DW (1999) Rapid detection and diagnosis of Septoria tritici epidemics in wheat using a polymerase chain reaction PicoGreen assay. Journal of Applied Microbiology 86: 701-708.

22. Zhan J, Fitt BDL, Pinnschmidt HO, Oxley SJP, Newton AC (2008) Resistance epidemiology and sustainable management of Rhyncosporium secalis populations on barley. Plant Pathology 57: 1-14.

23. Calderon C, Ward E, Freeman J, Foster SJ, McCartney HA (2002) Detection of airborne inoculum of Leptosphaeria maculans and Pyrenopeziza brassicae in oilseed rape crops by polymerase chain reaction (PCR) assays. Plant Pathology 51: 303-310

24. Fraaije BA Cools HJ, Fountaine JM (2005) Qol resistant isolates of Mycosphaerella graminicola and the role of ascospores in further spread of resistant alleles in field populations. Phytopathology 95: 933-941.

25. Lee HK, Tewari JP, Turkington TK (2002) Quantification of seed borne infection by Rhynchosporium secalis in barley using competitive PCR. Plant Pathology 51: $217-224$

26. McDonald BA, Zhan J, Burdon JJ (1999) Genetic Structure of Rhynchosporium secalis in Australia. Phytopathology 89: 639-645

27. Linde CC, Zala M, Ceccarelli S, McDonald BA (2003) Further evidence fo sexual reproduction in Rhynchosporium secalis based on distribution and frequency of mating-type alleles. Fungal Genet Biol 40: 115-125.

28. Barnes SE, Shaw MW (2003) Infection of hybrid primula seeds by Botrytis cinerea and latent disease spread through the plants. Phytopathology 93: 573 578.

29. Salamati S, Zhan J, Burdon JJ, McDonald BA (2000) The genetic structure of field populations of Rhynchosporium secalis from three continents suggests moderate gene flow and regular recombination. Phytopathology 90: 901-908.

30. Rajaguru BAP (2008) Molecular ecology of Botrytis cinerea. PhD thesis. University of Reading, Reading, UK.

31. Stedman OJ (1977) Effect of paraquat on number of spores of Rhynchosporium secalis on barley stubble and volunteers. Plant Pathology 26: 112-120.

32. Frac (2008) Fungicide Resistance Action Committee. 